\title{
STRATEGY OF PROMOTING LIBRARIAN'S PERFORMANCE IN CREATING USER'S SATISFACTION IN NATIONAL LIBRARY OF INDONESIA
}

\author{
Ahmad Masykuri \\ Perpustakaan Nasional Republik Indonesia \\ ahmadpnri@gmail.com
}

\begin{abstract}
The objective of this research is to determine the influence of the corporate culture, employee empowerment, librarianship training and work ethics towards employee performance (case study in National Library of Indonesia) Jl. Salemba Raya 28 A Jakarta, UPT Bung Karno Library in Blitar, and UPT Bung Hatta Library in Bukit Tinggi. The research approach is using quantitave method with path analysis. Sampling techniques is simple random sampling with a representative sample of 124 librarians. The data was collected through a Likert type structured questionaire toward variables. The next step is to test the validity by using the Pearson Product Moment test analysis and Realibility test by using Cronbach Alpha test and then the data was analyzed as requirement of statistic test; normality test error with Lilliefors, homogenity test and tests of significance and linearity of regression coefficients. The result such as: 1. Corporate culture, employee empowerment, librarianship training and work ethic has direct positive and significant effects towards performance. 2. Corporate culture and employee empowerment has direct positive and significant effects towards work ethic. 3. Employee empowerment has direct positive effects, but not significant to work ethics. Research implication showed the important of policy and chief regulatory about strengthen corporate culture, librarian empowerment equality and enhancement librarianship training.
\end{abstract}

Keywords: Performance, Corporate culture, employee empowerment, librarianship training, work ethic

National Library is a Govermental Institution - Non Ministry which Conducts the Goverment Duty in the field of Library functioning as Guidance Library, Reseach Library, Conservation Library and Net Work Center of Library, Located in the Capital of State.To conduct the librarian duty, it is demanded to have the high performance, adequate competence in developping and process library materials, and also they are able to serve the user's need quickly and accurately. Performance has the function of, attitude, competence.and action.Competence describes the characteristics of knowledge, skills, behavior and experience to perform a particular job or role effectively. (Wirawan, 2009:9).

The Librarian's action and attitude cannot be let from corporation culture constructed in one organization. That case is stated by Joko S Moelyono, stating, company's employee's performance will become better. It is related to the internal corporate culture. The employee who has understood all of organizational values will create those values as an organizational personality.Supporting perception will influence the performance and employee's satisfaction. Briefly, it can be concluded that corporate culture will influence corporate performance (Joko S, Moelyono, 2003; 41)

Where as Heskett $(1992 ; 11)$ stated : Corporate Culture can have significant impact on a firm's long term economic performance. We found that firms with cultures, that emphasized all the key managerial constituencies ( Customers, Stockholders and Employee's) and leadership from managers at all levels outperformanced firm that did not have those cultural traits by a huge margin

From the above opinion, it means that corporate culture can have the significant impact for long term - Economic performance. We found that the corporate culture emphazising all constituencies (Customer, Stakeholders and Employee) and all managers in all levels will have more competencies than the corporate who does not have any cultural traits with the huge margin.

The performance improvement can also be encouraged with the existance of employee's empowerment in one organization. This case is as stated by Wibowo ".Empowerment will encourage employee's to be involved more in creating organizational decision. 
Thus, this empowerment increases the competence and the sense of belonging to improve the sense of responsibility. So that the performance will also increase. Employees who are empowered are expected to conduct their job more that their authority given to them (Wibowo, 2009; 178). The experience and skill obtained through the empowerment will become the new knowledge and be able to given them the new motivation in running further job.

Where as Kenneh L Murrell and Mimi Meredith State : Truth be told, change can aften be a little frightening for many of us. It suggests the unknown, and we were not sure we'll be able to adapt successfully. Creating empowering organization can involve a lot of change, but it doesn't have to be a cause of anxiety and uncertainty if it informed and well planed. You now have the building blocks you need, and you'are ready to implement the actions that will build an empowering organization and result in higher performance thoughout your organization

From the above opinion, it can be concluded that occasionally the change will frighten because of the unknown condition. The well planned empowerment of employees in one organization should be anxious and it needs preparing its implementation to build the organization which empowers the employees and they will result the higher performance

The effort of National Libary in bureacratical reformation like " Improvement of Public Service, transparence, good governance and measurement of work achievement which is based on performance, encouraging govermental institution to do the cultural change in the organizational performance is determined by the existance of resource have high motivation, creative and are able to develop innovation, their performance will become better. Therefore it is needed the existance of effort to improve human resources competences. According to A. Mac Dougall and R Prytherch, training has become established in libraries as a primary activity affecting all areas of work, general staff morale, attitudes to users, competence, awareness and efficiency can all be enhanced by a regular and systematic sheme of training for all levels of staff. ( 1989; ix )

Training and Education have become the important establishment in the library as the main activity influencing all fields of work, generally moral staff, personality infacing the users, All competence conciousness, and efficiency can promote users by systematical scheme in holding training in all levels of employees. Through Librarianship Training and Education, It is expected that those training and education can give librarians knowledges and skills about librarian behavior. Therefore it will be easier and more skillful in performing their duties.

Where as the other performance promotion is the existance of employee's work ethic. This case is stated by Komarudin Khalil that "Work ethic is as work spiritual having the meaning the strongest motivation or energy that never extinguishes is from the faith of Allah. it is the sources of vertical relationship between people and their God. It is usefull for them selves and their atmosphere. Where as the reseach result of Donni Juni Priansa and Agus Garnida in Journal of Ecodemica (2015) shows that score R ( Correlation) for 0,874 . The contribution of work ethic influence by other factor that is not researched by other factor that is not researched in this research, this score is in the range $0,600-0,799$.

The result fixes with the concept which is stated by Anoraga (2014: 29) Stating that work ethic becomes the perception and attitude of a nation or people to the job. If individuals perceive that working is the sublime thing so their work ethic tend high and also on the contrary. Thus Librarian having the high ethic will work with the best result, usefull for both organization and people.

However, the fact in the field of library, shows that they are still some critics and sugestion about the performance of librarians or staffs. As stated in the data of user's complaint, there were 39 persons complaining and advising during in the year of 2015 and the most dominant problem is about the staff or librarian's in giving the users service for $67 \%$.Critic ad advises consist of feeling disappointment with attitude of librarians in serving users, they were unfriendly, lazy when they serve users and they don't master library substantially.15\% users complained about service 
system, $10 \%$ users complained about number of collection, $5 \%$ users complained other problem and services, Where as $3 \%$ users complained about the room facilities.

Based on the above background, the problem of fhis research is how to increase librarians performance with the hypothesis whether corporate culture employee's empowerment librarianship training and education will influence positively direct to work ethic and employee's performance?

This research give the siencetific answer frrom the problem of librarian performance increase in creating the satisfaction.

\section{Method of Research}

This research carried out in National Library of Indonesia Jalan Salemba Raya No 28 A Jakarta and Jalan Merdeka Selatan No 11 Jakarta and Library UPT Bung Karno, Blitar and also Library UPT Bung Hatta, Bukit Tinggi.

The approach of this research used is the quantitative research by using rendom sampling technique. To mesure the represntative sampling, the researchers use the formula of Slovin so that it will be obtained the number of representative sampling for 124 people from 180 population.

Data analysis technic is used discriptively to evaluate by hypothesis with line analysis ( path analysis). All hypotesis measurement are used by using Alpha 0.05 .

Before being measured the hypothesis, firstly it is carried out normality measurement from the error regression estimation by using Lilliefors Technic and significant measurement and registration liniarily by using ANAVA. To measure the direct and indirect influence from indepedent variable to dependent variable. Which is reflected in line coeficience. The program used is by using SPSS version 22 and microsoft excell.

\section{RESEARCH RESULT}

The result of measurement calculation from the simple signification correllation inter research variable do not show that all are significat in $\mathrm{a}=0,01$. That is the corporate culture employee's performance (r15) for 0.489 employee's employee's empowermen to employee's performance (r 25) for 0.208 . The training and education of librarianship to employees performance (r 30_form 0.503. The work ethic of employees (r 20 ) for 0.363 Employees empowerment to work ethic ( $\mathrm{r} 24)$ for 0.16 Training and education of librarianship to the work ethic (r24) for 0.401.

Summary of simple coofeciency inter variable research is as follows:

Table 1 Simple Correlation Coefficiency between Correlation Research Variable

\begin{tabular}{|l|l|l|l|l|l|}
\hline & $\mathrm{Y}$ & $\mathrm{X} 1$ & $\mathrm{X} 2$ & $\mathrm{X} 3$ & $\mathrm{X} 4$ \\
\hline Y Pearson Correlation & 1 &, $489 ”$ &, $208^{\prime \prime}$ &, $503 ”$ &, $501 ”$ \\
Sig ( 2 tailed) & &, 000 &, 020 &, 000 &, 000 \\
$\mathrm{~N}$ & 124 & 124 & 124 & 124 & 124 \\
\hline X1 Pearson Correlation &, $489 ”$ & 1 & $-0,14$ &, $296 ”$ &, $363 ”$ \\
Sig ( 2 tailed ) &, 000 & &, 879 &, 001 &, 000 \\
N & 124 & 124 & 124 & 124 & 124 \\
\hline X2 Pearson Correlation &, $208 ”$ & $-0,14$ & 1 &, 008 &, 016 \\
Sig ( 2 tailed ) &, 020 &, 0879 & &, 930 &, 0856 \\
N & 124 & 124 & 124 & 124 & 124 \\
\hline X3 Pearson Correlation &, 503 &, $296 ”$ &, 008 & 1 &, 401 \\
Sig ( 2 tailed ) &, 000 &, 001 &, 930 & &, 000 \\
N & 124 & 124 & 124 & 124 & 124 \\
\hline X4 Pearson Correlation &, 501 &, 363 &, 016 &, 410 & 1 \\
Sig ( 2 tailed) &, 000 &, 000 &, 856 &, 000 & \\
N & 124 & 124 & 124 & 124 & 124 \\
\hline
\end{tabular}

**. Correlation is significant at the 0.01 level (2-tailed). 
*. Correlation is significant at the 0.05 level (2-tailed).

From the above table, it shows that not all corelation in each clear of data is showsthe significancy, further it is done the hypothesis measurement which is done by using line analysis.The result of the hypothesis decision is as follows:

\section{Model structural 1}

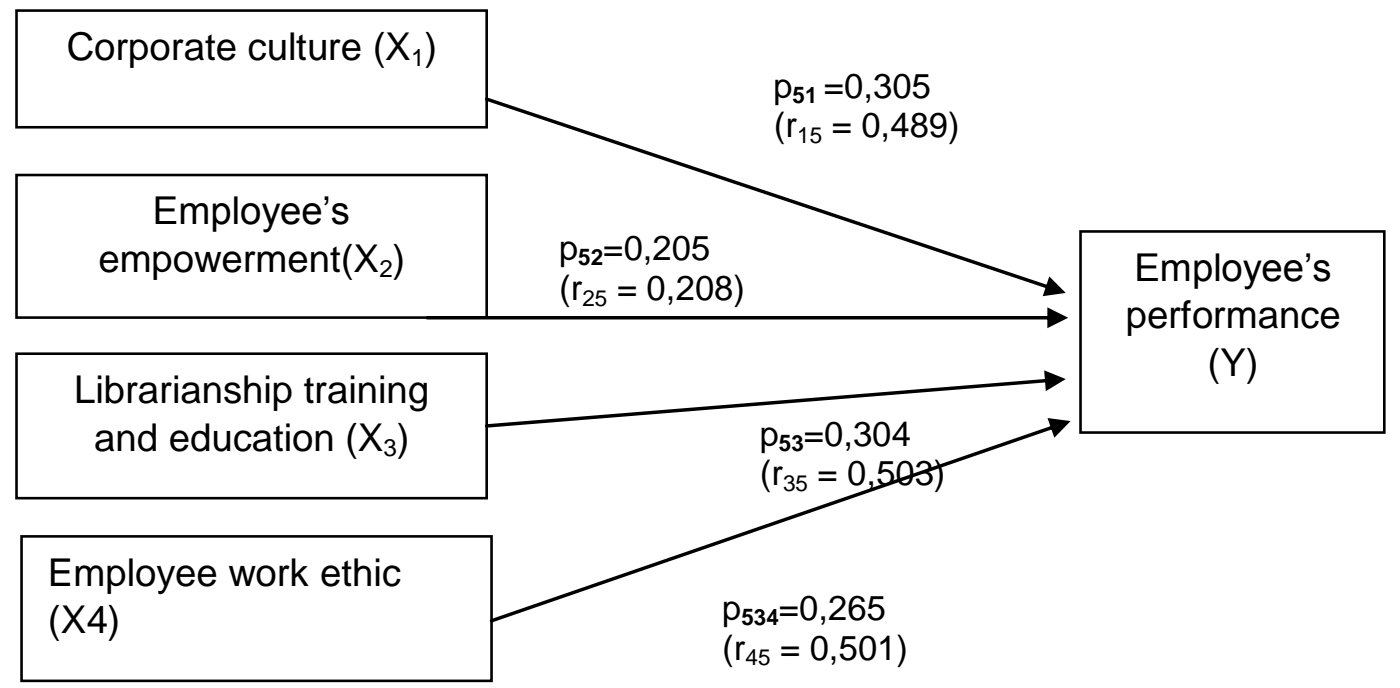

Picture 1.Empirical Model of Structural Relations 1 Based on the Calculation Result of Path Analysis.

a. Corporate culture influence positively direct to employee's performance

Line coefficiency influences the corporate culture to employee (P 51) for 0.305 with calculated 4.228 to $\mathrm{a}=0.05$ obtained with table 1979 because the score $\mathrm{t}$ calculated $(4,228)>\mathrm{t}$ table 1,979 , so that Ho is rejected, it means that coefficiecy of corporate culture line to employee's performance (P 51) is significant.

Based on this founding, it can be concluded that corporate culture (x1), influences positively direct to employee's performance (Y)

b. Employee's empowerment influences positively direct to employee's performance.

Line coefficiency of employee's empowerment influences to employee's performance ( P 52) for $0,205$ with $t$ calculated 3100 ar $\mathrm{a}=0,05$ gained $\mathrm{t}$ table 1,979. Since score of $\mathrm{t} t$ calculated ( 3.100$)$ $>\mathrm{t}$ table $(1,979)$ so that $\mathrm{H} 0$ is rejected. It means that line coeficiency of employee's empowerment, to employee's empowerment ( P52) is significant. Based on the founding, it can be concluded that employee's empowerment (X2) influences positively direct to employee's performance (Y)

c. Librarianship Training and Education influences positively direct to employee's performance.

The influence of line coefficiency from Librarianship Training and Education to Employee's performance ( P 53 ) for 0,304 with $\mathrm{t}$ calculated 4,139 at $\mathrm{a}=0,05$ obtained $\mathrm{t}$ table 1,979 because the score of $t$ calculated $(4,139)>t$ table $(1,979)$

There for $\mathrm{H} 0$ is rejected,it means that line coefficiecy of Librarianship Training and Education to employee's performance (P53) is significant, Based on the founding it can be concluded that Librarian Training and Education ( X3) influences positively direct to employee's performance (Y)

d. Work ethic influences positively direct to employee's performance 
Influence coefficiency of work ethic to employee's performance ( P 54 ) for 0,265 with $\mathrm{t}$ calculated 3,522 at a $=0,05$ obtained $\mathrm{t}$ table 1,797. Because the score of $\mathrm{t}$ calculated $(3,522)>\mathrm{t}$ table ( 1,979$), \mathrm{H} 0$ is rejected. It means that line coefficiency of work ethic to employee's performance ( P 54 ) is significant. Based on the founding it can be concluded that work ethic ( $\mathrm{X} 4$ ) influences positively direct to employee's prformance. (Y).

\section{Substructural Model 2}

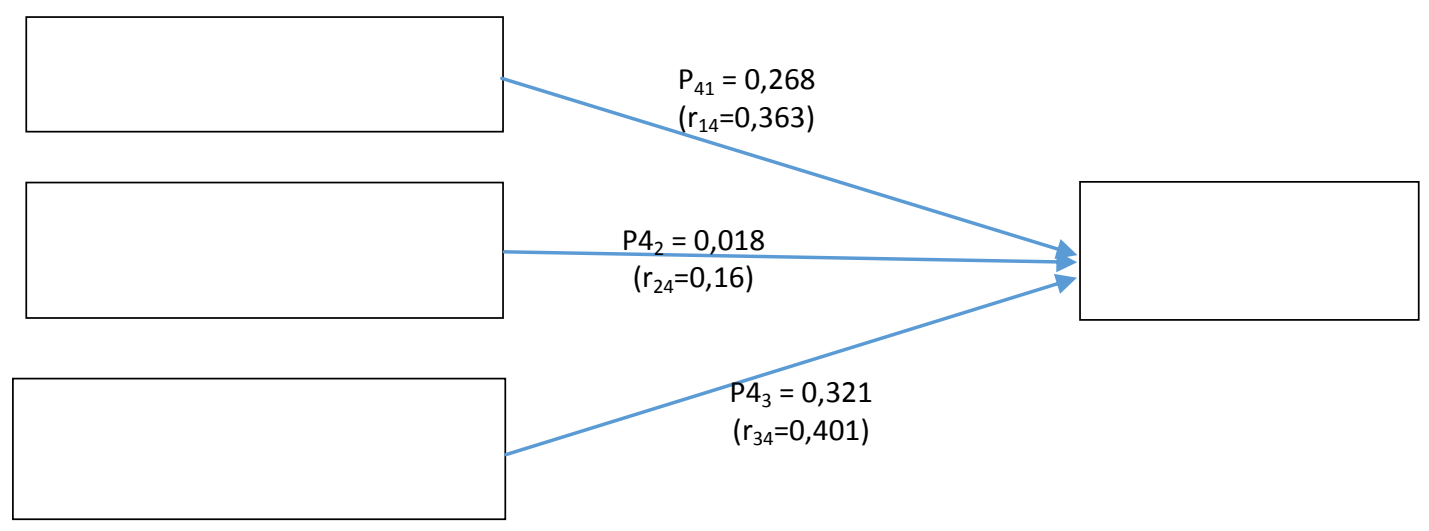

Picture 2. Empirical Model of Structural Relationship 1 based on path analysiscalculation.

\section{a. Coorporate Culture Influences Positively Direct To The Work Ethic.}

Line coefficiency of corporate culture influence to work ethic ( P 41 ) for 0,268 with calculated 3,191 at $\mathrm{a}=0,05$ obtained $\mathrm{t}$ table 1,979. Since the score of $\mathrm{t}$ calculated $(3,191)>t$ table $(1,979)$ $\mathrm{H}_{0}$ is rejected. It means that line coefficiecy of Corporate Culture Work Ethic $\left(\mathrm{P}_{41}\right)$ is significant. Based on these findings, it can be concluded that corporate culture (X1) influences positively direct to work ethic ( X4)

\section{b. Employee Empowerment Influences Positively Direct To The Work Ethic.}

From the calculation of coefficient value of the path (p42) of 0.018 with tcount of 0.220 at $\alpha=$ 0.05 obtained $t$ table 1.979 . Because the value of $t$ count $(0,220)<$ ttable $(1,979)$, then $\mathrm{H} 0$ is accepted, it means that coefficient of employee empowerment path to work ethic (p42) is not significant. Based on these findings, it can be concluded that employee's empowerment (X2) has no direct effect on work ethic (X4).

c. Librarianship Training and Education Influences Positively Direct To Work Ethic.

From the calculation of coefficient (p43) of 0.321 with tcount 3,821 . At $\alpha=0.05$ obtained $t$ table 1.979. Because tcalculated $(3,821)>$ ttable $(1,979), \mathrm{H} 0$ is rejected, it means that the coefficient of librarian training path to work ethic (p43) is significant. Based on these findings, it can be concluded that the training of librarianship (X3) has a direct positive effect on the work ethic (X4).

These are summarizes results of the research between variables

\begin{tabular}{|c|c|c|c|c|}
\hline \multirow{2}{*}{ Path } & \multirow{2}{*}{ Path coefficient } & \multirow{2}{*}{$\mathbf{t}_{\text {count }}$} & \multicolumn{2}{|c|}{$\mathbf{t}_{\text {table }}$} \\
\cline { 4 - 5 } & 0,305 & $4,228^{*}$ & $\mathbf{a}=\mathbf{0 . 0 5}$ & $\boldsymbol{\alpha}=\mathbf{0 . 0 1}$ \\
\hline $\mathrm{p}_{51}$ & 0,205 & $3,100^{*}$ & 1,979 & 2,616 \\
\hline $\mathrm{p}_{52}$ & 0,304 & $4,139^{*}$ & 1,979 & 2,616 \\
\hline $\mathrm{p}_{53}$ & 0,265 & $3,522^{*}$ & 1,979 & 2,616 \\
\hline $\mathrm{p}_{54}$ & 0,268 & $3,191^{*}$ & 1,979 & 2,616 \\
\hline $\mathrm{p}_{41}$ & 0,018 & 0,220 & 1,979 & 2,616 \\
\hline $\mathrm{p}_{42}$ & 0,321 & $3,821^{*}$ & 1,979 & 2,616 \\
\hline $\mathrm{p}_{43}$ & \multicolumn{3}{|c}{} \\
\hline
\end{tabular}


From the table, it shows that not all correlations at each pair of data show the significancy, further it is done the hypothesis measurement by using line analysis. The result of hypothesis desicion is as follows.

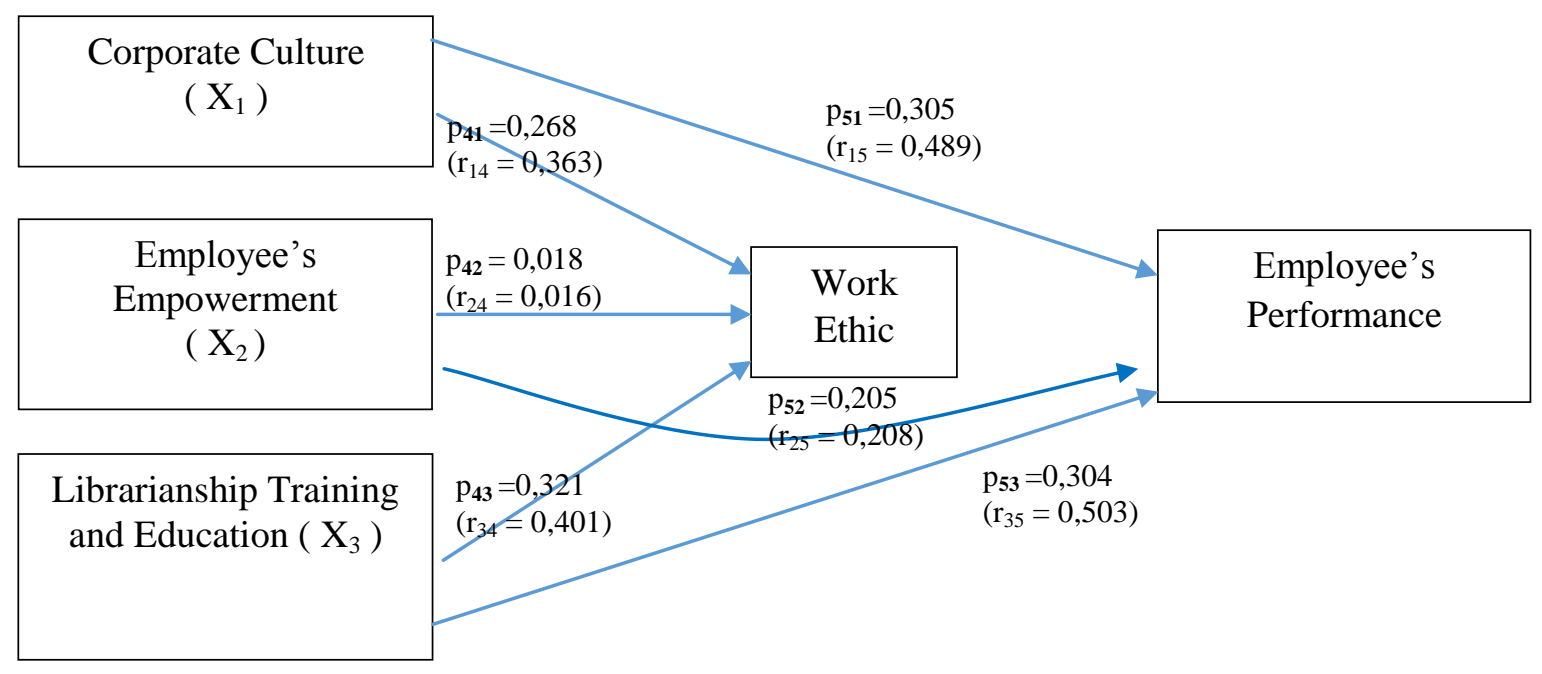

Picture 3. Emperical Model of Structural Relationship inter variable based on calculation Result of pathanalysis

\section{Discussion of Research Result}

\section{Influence of Corporate Culture to Employee's Performance.}

The result of hypothesis measurement above shows that corporate culture influence positively direct and significant to the employee's performance. This case shows thatemployee's performance can be promoted by strenghtening the corporate culture. The problem of minimizing the work result target can be overcome with determination of work standard and the achieve target at every working unit completed with Standard of Operational Procedure (SOP) and clear work guidance in detail. It is hoped that Librarians are easy to understand them. Beside that it is needed application system of performance appraisal based on informatic technology and communication which can monitor the employee's work result anytime.

To strenghten corporate culture, it is needed the existance of leader's role in giving the enlightment, socialization and encouragement to all employee's to follow the existance of corporate culture.Beside that the role of leader to carry out the culture transformation is very important, especially in harmonizing, The new values such as : Giving the users the quick service, using the new management standard, development of informatic technology and professionalism will show the successof producethe corporate culture establishment.

Stated by Terrence E. Deal and Allan A Kennedy (2000:251),astrong and revitalized business culture, attuned to prevailing environment, so be capable of producing extraordinary result. But no organization has ever raised the performance bar without having both the management and leadership to acheive higher standards.Revitalization of the strong corporate culture adjusted to be done for the capable atmosphere to the extraordinary production, but there is no organization which can be promoted without management and leadership set high standard.

\section{Influence of employee's empowerment to employee's peforrmance}

The next result of hypothesis measurement shows that employee's empowerment influences positively and significantly to the employee's performance. This case means that the increase of employee's empowerment will effect the increaseof their performance.

The empowerment is the change occured in the phylosophy of management which can create each individuals to use their ability and energy to reach the organizational objective. The leaders who 
delegate a part of their autority to their subordinates to finish a duty will be welcome well by them as a trusty and also other employee's responsibility.Consequently they will effort not to be failed or decreased their achievement.

The Librarian involved in one team will grow his feeling as a part of member. The satisfied feeling growth will run his responsibility to carry out his duties.There is a feeling that running the precious thing and obtaining the pleasure in doing the communication and cooperation with other employee's.

\section{Influence of Librarianship Training and Education to Employee's Performance}

The result of hypothesis measurement above shows that librarian influences positively direct and significant to employee's performances. This case shows of employee's performance is also influenced by the intensity of librarians in joining some trainings.

The training is the human resources development which is designed specifically for development of knowledges, skills, competences, attitude and employee's personality in developping employee's performance in running their jobs for the time being. The end of training recently can not be focused on the technical training only, but also it concerns about the marginal. Soft skill needed by employee's. The need of training relates with people service demand and development of knowledge and technology which grow on and on.

According to Gary Dessler ( $2008 ; 280$ ), training has the role in performance management process. Training is the integrated process used by the entrepreneur to make sure that some employee's work to achieve the organisational objective. It means that the entrepreneurs carry out the integrated approach and orient in objective to assign, train, appraise and give the reward to some employee's. Running managerial approach or performance means that all efforts of training done must be adjusted with the goals required by the entrepreneurs to be given to each employee in order that the company's objective can be achieved.

The needs of training and education in National Library is very important considering that developmet of any kind of library material in digital shapes requires library material processing more specifically with new standard which can adopt the international development. Beside that, there is a demand from librarians completing the specific competence such as for collection development, library material processing and user's service. So that it is needed the training in the field of librarianship.

\section{Influence of Work Ethic to work Performance}

The next results of hypothesis measurement shows that work ethic has the positively direct influence which is significant with employee's performance. This case shows that some librarians have the high work ethic based on the independence and high confidencen in doing their duties which the principle of performance results are determined by them selves and those performance will have the impact to organizational success.

As stated by K.S Chong and Benyamin Y.K that are sorted by Wirawan,Work Ethic belief system pertains to ideas that stress individualism/ independence and the positive effect of work on individuals. Work is the considered good in itself because it dignities a person. Making a personal effort to work hard wil ensure success".

Work Ethic regarding to idea strenghtening individualism or independency and positive influence work individually working will be supposed the good thing because it can be increase the social status life from someone, efforting to work hard will ensure the success.

\section{Influence of corporate culture to work Ethic}

The result of hypothesis measurement next shows the corporate culture has the positively and significantly direct influence to the employee's performance. This case shows that the strong corporate culture can promote the work ethic of employee's. 
Corporate culture can help the organization reach the success by optimizing the corporate culture maximally. Organization needs to establish the same values to each individual. The sense of togetherness in following culture or the same values creating the unity and trusty from each employee. Consequently there will be the high spirit and motivation of work. Thus, there will be the good and health atmosphere. That atmosphere will create the creativity and commitment so that finallythey are able to accomodate the change in organization positively.

Corporate culture becomes the intangible strength behind organizational factors which visible and can be observed. Culture is as the social energy which makes the member of organization work. This case is stated by Wirawan $(2007 ; 3)$ "Corporate Culture motivates the member of organization to reach the organizational goal, they are also motivated to behave with the special maner. That manner can be accepted by Corporate Culture". This case shows that the importance of Corporate Culture which can promote the member's motivation in finishing their assignments, so that the work ethic of employee's will keep being high because their understanding and value implementation, norms and organizational rules will be obeyed.

\section{Influence of Employee's Empowerment to work Ethic}

The further employee's empowerment does not influence directly to work ethic, that P42 for 0,018 reflect the lowest influence among the others.

This case shows that the frequence of librarian empowerment does not increase work ethic of employees significantly.

This case can be caused since there is the sense of confidence from librarians so that their potential and self competences become independent and show their highwork ethic. By having the sense of self confidence, they will contribute to do their duties because they feel very meaningfull for organization and their roke can be worthfull for some people.

Thus, the librarians obtain their best self actualization and personality development so that they groe their high work ethic in doing their assignment.

The hight of Librarians work ethic is caused by the comfort of work atmosphere which does not have any conflicts inter librarians and also the high attention of superior to librarian therefore that high attention creates the high work ethic.

This case can be concluded that research result done by Husen Sutisna who states that " The characteristic of work situation has the real relation with employee's work ethic where as the work characteristic does not have any real relationship with employee's work ethic. The real relationship is occured between individual characteristic and employee's work ethic. It can be seen at opportunity score (sig).

The measurement for 0,001 is smaller than 0,05 . The shape of relationship is rather weak with correlation score (r) for 0,451 . The better characteristic of individual is the better employee's work ethic. The real relationship between characteristic of work situation and employee's workethic, can be seen at opportunity score ( sig) measuremen for 0,043 which is smaller than 0.05 . The form of this relationship is rather weak with correlation score (r) for 0,2777 . The better employee's work ethic.

The work characteristic does not have the real relation with employee's work ethic, it can be seen from oportunity score (sig) measurement for 0,095 which is higher than 0.05 with correlation score (sig) for 0,230 . It means that the work characteristic is predicted that there is no influence to the employee's work ethic. Between work motivation and workemployee'sethichave the real relationship. This case is identified from oportunity score ( $\mathrm{sig}$ ) measurement for 0,003 which is smaller than 0,05 . The form of their relationship is rather weak with correlation score (r) for 0.398 . The better work motivation of employees, they will be better their work ethic.

The employees with individual characteristic, their work characteristic and the high work atmosphere characteristic in their work will tend they will have the high work ethic or have the work hard character, smart work and heartfelt work.. 


\section{Influence of Librarianship Training and Education to work ethic}

Further the result of hupothesis measurement shows that librarian training and education has the significant and positive influence to work ethic. In this research result, it shows that the biggest influence to be compaire with other variable is 0,321 ( P43). This case is caused that training it is strenghtened with attitude of work hard, without giving up, always ready in giving services and keeping the librarians ethic. As stated by Simamore (2004;273) " Training and education become learning process involving the skill, concept, rules or attitude to promote the employees performances.

The implementation of training and education becomes the up grading for employee's which can refreshen their work spirit, promotion and deepening the knowledge achieved so that this training and education can prepare the excellent and competitive human resources who are able to create the organizational actualization.

\section{CONCLUSION}

Based on the statical calculation and hypothesis measurement and also discussion, it is obtained the founding result as follows:

1. Corporate Culture influences positively direct to employee's performance. This case reflects and proves that strong corporate culture will increase employee's performance in National Library

2. Employee's empowermet influence positively direct to Employee's Performance. This case reflects and proves that the frequent employee's empowerment will increase the employee's performance in National Library.

3. Librarianship Training and Education influences positively direct to the employee's performance.This case reflects ad proves that the frequent training and education of librarianship will promote the employee's performance in National Library.

4. Work ethic influences positively direct to the employee's performance. This case reflects and proves that the biggest employee's work ethic will promote the employee's performance in National Library.

5. The Corporate Culture influences positively direct to the employee's work ethic. This case reflects and proves that the strong corporate culture will increase the work ethic of employees in National Library.

6. Employee's Empowerment does not influence directly to the work ethic of employee's. This case reflects and proves that the frequent employee's empowerment does not improve the employee's work ethic in National Library.

7. Librarianship Training and Education influences positively direct to employee's work ethic. This case reflects and proves that the frequent training and education of librarianship will improve the work ethic in National Library

Implication in this research is as follows:The reseach will influence in planning and budgeting of strenghtening activity of corporate culture involving all work unites by socializing vision and missiion of organization, establising disciplin and implementing Libraran's Ethic Code and Some Norms in Organization. Beside that this research will also enlight the superiors in empowering some librarians in all activities and develop the concept through training and education that is only to improve their work ethics.

\section{REFERENCES}

Anoraga,Panji. (2014).Psikologi kerja. Jakarta: Rineka Cipta.

Deal Terrence E. dan Kennedy, Allan A. (2000).The new corporate cultures : revitalizing the workplace after downsizing, mergers, and reengineering. Cambridge: Perseus Publising.

Dessler, Gary. (2008). Manajemen sumber daya manusia. Jakarta: Indeks.

Dougall, A. Mac \&. Prytherch, R. (1989). Cooperative training libraries. England: Gower Don Publising Company Limited.

Khalil, Komarudin. (2011).Etos kerja berbasis spiritual. Bandung: Siinnergy Publising. 
Kotter, John P \& Heskett, James L. (1992).Corporate culture and performance. New York: The Free Press.

Mimi Meredith. Murrell. (2000). Empowering Employees. New York: McGraw-Hill.

Moeljono, Djokosantoso. (2003). Budaya korporat dan keunggulan korporasi. Jakarta: Elex Media Komputindo.

Priansa, Donni Juni, Garnida, Agus . (2015). Pengaruh Kepemimpinan Visioner Dan Etos Kerja Terhadap Kinerja PegawaiBank Syariah Mandiri. Jurnal Ecodemica . V o 1. I I I . N o . 1 April (http://ejournal.bsi.ac.id/ejurnal/index.php/ecodemica/article/view/65/42 diakses tanggal 21 Juli 2017

Simamora, Henry. (2004). Manajemen Sumber Daya Manusia Edisi III. Yogyakarta: Bagian Penerbitan Sekolah Tinggi Ilmu Ekonomi YKPN.

Sutisna, Husen. (2008). Analisis Hubungan Motivasi Kerja Dengan Etos Kerja Karyawan (Studi Kasus Karyawan Fakultas Pertanian Ipb) Oleh Program Sarjana Ekstensi Manajemen Agribisnis Fakultas Pertanian Institut Pertanian Bogor 2008https://core.ac.uk/download/pdf/32338824.pdf diakses tanggal 25 April 2017

Wibowo. (2009).Manajemen Kinerja. Jakarta: Rajawali Pers.

Wirawan. (2015). Manajemen Sumber Daya Manusia Indonesia. Jakarta: Rajagrasindo Persada.

Wirawan. (2007). Budaya dan Iklim organisasi: teori aplikasi dan penelitian. Jakarta: Salemba Empat.

Wirawan. (2009). Evaluasi kinerja Sumberdaya Manusia. Jakarta: Salemba Empat. 